\title{
A NEW SET OF CERTIFIED REFERENCE MATERIALS OF THE CHEMICAL COMPOSITION OF THE IRON ORES
}

\author{
NOWA SERIA CERTYFIKOWANYCH MATERIAŁÓW ODNIESIENIA \\ SKŁADU CHEMICZNEGO RUD ŻELAZA
}

The study assumed the production of ten certified reference materials of the chemical composition of raw ores, magnetite and hematite concentrates and pellets. The raw materials were obtained from Ukraine, Russia, Liberia, Brazil, Canada, and Norway. Their chemical composition was confirmed by the WD $X R F$ method, and the mineral composition was analyzed with the use of X-ray diffraction. Radioactivity studies were also carried out. Dried, ground and mixed materials were subjected to homogeneity tests, which were carried out on samples melted in a mixture of lithium borates, using a ZSX Primus 2 X-ray spectrometer. Based on the results of the homogeneity test and the use of analysis of variance (ANOVA) for the results of individual determinations, the contribution of homogeneity in the uncertainty of the certified value was calculated. International certification round-robin program of tests with fourteen laboratories was organized and carried out. The results of the analyses were developed statistically in accordance with ISO Guide 35:2017. Certificates, data sheets and labels were developed. The production was carried out in accordance with the requirements of PN-EN ISO 17034.

Keywords: certified reference materials, chemical composition, iron ores, concentrates, pellets
Zaplanowano wytworzenie dziesięciu wzorców sktadu chemicznego rud żelaza, obejmujacych rudy surowe, koncentraty magnetytowe $i$ hematytowe oraz pelety. Pozyskano surowce pochodzace z Ukrainy, Rosji, Liberii, Brazylii, Kanady i Norwegii. Potwierdzono ich sktad chemiczny metoda WD XRF, przeprowadzono badania radioaktyroności oraz badania sktadu mineralnego. Wysuszone, rozdrobnione $i$ reymieszane materiaty poddano badaniom jednorodności, które przeprowadzono na próbkach stopionych w mieszaninie boranów litu, z wykorzystaniem spektrometru rentgenowskiego ZSX Primus 2. Woparciu o wyniki badania jednorodności, stosujac analizę wariancji (ANOVA) royników pojedynczych oznaczeń, wyliczono udziat jednorodności materiału w nieperwości wartości atestowanej. Zorganizowano $i$ przeprowadzono międzynarodowe badania atestacyjne z udziatem czternastu laboratoriów. Wyniki analiz atestacyjnych opracowano statystycznie zgodnie z przewodnikiem ISO Guide 35:2017. Opracowano świadectwa, kartę katalogowa $i$ etykiety. Cała produkcja przebiegta zgodnie z wymogami normy PN-EN ISO 17034.

Stowa kluczowe: certyfikowane materiaty odniesienia, sktad chemiczny, rudy żelaza, koncentraty, pelety

\section{INTRODUCTION}

An evaluation of the usefulness of iron ore for steel production process, i.e. the calculation of the real value and its influence on the cost of the product, is possible on the basis of the results of a full chemical analysis of the ore. Most methods of controlling of chemical composition used in the industry and in trade settlements of metallurgical raw materials require the use of natural chemical composition certified reference materials (CRM). For the proper analytical process, especially with instrumental methods, it is necessary to use CRMs with a chemical and mineralogical composition as similar as possible to the analysed material. The main source of iron-bearing raw materials for Polish steelworks is still Ukraine and also Russia, but more and more often supplies from these directions include a new range of materials. The ores from African (Liberia) and South American (mainly Brazil) deposits are also becoming increasingly important. The usefulness of raw materials (especially he-

Corresponding Author: grazyna.stankiewicz@imz.pl matite concentrates) from Canada and Norway is also being analysed.

So, in the year 2017, Instytut Metalurgii Żelaza together with Polcargo Medyka started activities aimed at supplementing and extending the existing offer of certified reference materials of the chemical composition of iron ores $[1,2]$. The project was assumed the production of a tenpart serie, marked with symbols 3.50-3.59, including: three magnetite concentrates: L-Gok 70\% (No. 3.50), Ju-Gok (No. 3.51), Ingulecki Gok (No. 3.52); two hematite concentrates: Mount Wright No. (No. 3.53), Mo I Rana (No. 3.54); three raw ores: Mount Tokadeh DSO (No. 3.55), Carajas (No. 3.56), Standard Sinter Feed Tubarao (No. 3.57) and two pellets: L-Gok alkaline (No. 3.58) and Sev-Gok (No. 3.59).

\section{PRODUCTION STAGES OF CERTIFIED REFERENCE MATERIALS}

The stages of the production of certified reference materials for the chemical composition of powder materials in- 
clude: sampling, drying, separation of any contaminants, radioactivity testing, control analysis of chemical composition, mineral composition testing, grinding, mixing, sieve analysis, homogeneity testing, preparation of documentation, sampling for certification analysis, selection of Polish and foreign laboratories for international certification round-robin program, and statistical evaluation of the certification analysis. Issuing certificates and catalogue sheets and packing is the final stage of production.

\subsection{SAMPLING AND PRELIMINARY CHARACTERISTICS OF CANDIDATE MATERIALS}

The primary samples of candidate materials were taken either directly from wagons (magnetite concentrates and pellets) or from over-tone packaging (hematite concentrates and raw ores). First, the materials were scattered as thin layers on tarps, dried at room temperature, depending on the degree of moisture, for four to six days, after which the radioactivity tests were carried out using an Exploranium GR320 Lab Spec spectrometer. For all samples tested, the concentration level of radioactive substances was less than $0.02 \mathrm{~Bq} / \mathrm{g}$.

Then, after drying twenty-gram portions of the materials at $105^{\circ} \mathrm{C}$, the loss on ignition was determined at $1050^{\circ} \mathrm{C}$ and the chemical composition was analysed using titration method for the determination of $\mathrm{FeO}$ and the WD XRF method for determining other basic ingredients. In addition, phase composition tests were carried out. Using the X-ray diffraction method, more than $90 \%$ of magnetite and about $1 \%$ of hematite and siderite were found in the magnetite concentrates; the minerals of the gangue are primarily quartz and carbonates - dolomite and magnesite.

Hematite concentrates showed the presence of more than $90 \%$ of hematite and about $3 \%$ (Mo and Rana) or $5 \%$ (Mount Wright) of magnetite. The basic minerals of gangue in the Mo and Rana concentrate are quartz, ankerite and biotite, and in Mount Wright - quartz and dolomite. Studies of the phase composition of raw ores revealed that the ore richest in hematite $(>80 \%)$ is Carajas, containing more than $7 \%$ of goethite and less than $0.5 \%$ of magnetite. SSFT and Liberian ores are characterised by more than $50 \%$ of hematite content. In the Liberian ore, unlike SSFT, more than $12 \%$ of goethite and more than $6 \%$ of magnetite were also found. In the SSFT ore, the total content of these minerals is at $5 \%$. The basic ingredient of gangue is quartz (in the Brazilian ores) or quartz and calcite (in the Liberian ore). The content of individual phase components in pellets is also diversified. While in the L-GOK basic pellets the content of hematite exceeds $70 \%$, in the Sev-GOK pellets it is only up to $50 \%$ at a content of about $7 \%$ magnetite. The minerals of gangue are dolomite, quartz and magnesite in the L-GOK pellets, and quartz, calcite, and muscovite in the Sev-GOK pellets.

The initial granulation of individual materials was as follows: Ju-GOK concentrate $<80 \mu \mathrm{m}$, L-GOK concentrates $70 \%$ and In-GOK, as well as Sev-GOK and L-GOK basic pellets $<100 \mu \mathrm{m}$, Mo and Rana concentrate $<500 \mu \mathrm{m}$, Mount Wright concentrate and Mount Tokadeh Liberian ore $<1.6 \mathrm{~mm}$, Brazilian ore SSFT and Carajas $<3.15 \mathrm{~mm}$. Magnetite concentrates and pellets did not require additional grinding. However, hematite concentrates and lumpy raw ores (after initial crushing in a jaw breaker) were further grained in a vibratory ring mill to a grain size below $200 \mu \mathrm{m}$. The dried and shredded materials were mixed in

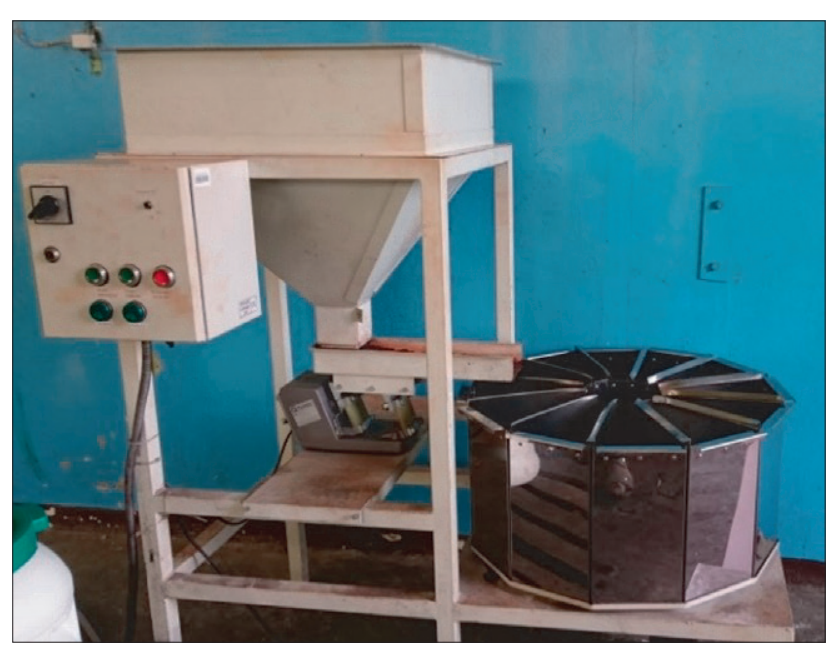

Fig. 1. Twelve-position separator for powder materials used to homogenise of the materials

Rys. 1. Dwunastopozycyjny rozdzielacz materiałów sypkich wykorzystany do ujednorodniania materiałów

a twelve-position bulk material separator (Fig. 1). After the last division, two independent samples were taken from each of the twelve containers to determine the homogeneity of the materials. Also, one hundred-gram samples for sieve analysis were taken from one of the containers. After the last division, two independent samples were taken from each of the twelve containers to determine the homogeneity of the materials. One hundred-gram samples were also taken from one of the containers for sieve analysis.

\subsection{SIEVE ANALYSIS}

A traditional sieve analysis was carried out for one hundred-gram samples taken from each homogenised material. For example, the results given in Table 1 were obtained for magnetite concentrates and pellets. Over $86 \%$ of the mass of each concentrate had a grain size below $45 \mu \mathrm{m}$, and in the Ju-GOK concentrate only about $2 \%$ of the material had a grain size above this value.

Tabela 1. Analiza sitowa koncentratów magnetytowych i peletów Table 1. Sieve analysis of magnetite concentrates and pellets

\begin{tabular}{|l|r|r|r|r|r|}
\hline \multirow{2}{*}{ Grain size, $\boldsymbol{\mu m}$} & \multicolumn{5}{|c|}{ Mass fraction, \% } \\
\cline { 2 - 6 } & \multicolumn{1}{|c|}{$\mathbf{3 . 5 0}$} & \multicolumn{1}{c|}{$\mathbf{3 . 5 1}$} & \multicolumn{1}{c|}{$\mathbf{3 . 5 2}$} & \multicolumn{1}{c|}{$\mathbf{3 . 5 8}$} & \multicolumn{1}{c|}{$\mathbf{3 . 5 9}$} \\
\hline$<100$ & 100.00 & 100.00 & 100.00 & 100.00 & 100.00 \\
\hline from $<100$ to $>80$ & 0.82 & 100.00 & 3.07 & 13.40 & 15.80 \\
\hline from $<80$ to $>63$ & 1.69 & 0.15 & 1.82 & 5.93 & 6.31 \\
\hline from $<63$ to $>50$ & 4.82 & 0.87 & 1.66 & 4.01 & 4.93 \\
\hline from $<50$ to $>45$ & 6.52 & 1.22 & 1.56 & 3.60 & 2.67 \\
\hline$<45$ & 86.15 & 97.76 & 91.89 & 73.06 & 70.29 \\
\hline
\end{tabular}

Tabela 2. Zróżnicowanie zawartości $\mathrm{Fe}, \mathrm{CaO}, \mathrm{SiO}_{2} \mathrm{i}_{2} \mathrm{Al}_{2} \mathrm{O}_{3}$ w poszczególnych frakcjach ziarnowych materiałów kandydackich na wzorce 3.58 i 3.59

Table 2. Diversification of $\mathrm{Fe}, \mathrm{CaO}, \mathrm{SiO}_{2}$ and $\mathrm{Al}_{2} \mathrm{O}_{3}$ content in individual grain fractions of candidate materials 3.58 and 3.59

\begin{tabular}{|l|c|c|}
\hline \multirow{2}{*}{ Component } & \multicolumn{2}{|c|}{$\left(\mathbf{C}_{\max }-\mathbf{C}_{\min }\right) / \mathbf{C}_{\text {max }} \cdot \mathbf{1 0 0 \%}$} \\
\cline { 2 - 3 } & $\mathbf{3 . 5 8}$ & $\mathbf{3 . 5 9}$ \\
\hline $\mathrm{Fe}$ & 1.1 & 1.8 \\
\hline $\mathrm{CaO}$ & 14.8 & 9.3 \\
\hline $\mathrm{SiO}_{2}$ & 14.0 & 15.6 \\
\hline $\mathrm{Al}_{2} \mathrm{O}_{3}$ & 4.5 & 7.7 \\
\hline
\end{tabular}


In order to determine the content of components in individual fractions, beads were made from each grain fraction, and their chemical composition was determined with the use of the WD XRF method. Table 2 shows, for example, the variation in $\mathrm{Fe}, \mathrm{CaO}, \mathrm{SiO}_{2}$ and $\mathrm{Al}_{2} \mathrm{O}_{3}$ content in individual grain fractions of candidate materials 3.58 and 3.59. The results of the homogeneity test determined the suitability of the candidate materials for the next steps of production of certified reference materials.

\subsection{HOMOGENEITY TESTS}

The homogeneity tests were carried out with the use of the chemical composition of 24 samples taken from candidate materials after mixing stage. The $\mathrm{FeO}$ content was determined with the use of titration, $\mathrm{MgO}$ and $\mathrm{Na}_{2} \mathrm{O}$ with ICP OES, $\mathrm{C}$ with HFIR method, and GOI and LOI with gravimetric method. The other components were determined using routine WD XRF analytical procedures for iron ore analysis, after melting the samples in a mixture of lithium borates. The analysis of variance (ANOVA) for the above results of individual determinations was used for the calculation of the contribution of the inhomogeneity of the material in the uncertainty of the certified value. This uncertainty is expressed as $u_{\text {hom }}$ [2]. The uncertainties associated with heterogeneity were determined in accordance with the ISO 35 Guide [3] and based on:

- between-group variance $-M S_{\text {between }}$
- within-group variance - $M S_{\text {within }}$ using the formula:

$$
u_{\text {hom }}=\left(\frac{\left[M S_{\text {between }}\right]-\left[M S_{\text {within }}\right]}{n_{0}}\right)^{0.5}
$$

If the difference $\left(M S_{\text {between }}-M S_{\text {within }}\right)$ was less than zero, $u_{\text {hom }}$ value was calculated in accordance with the guidelines of the Guide [3] using the formula proposed by Linsinger [4]:

$$
u_{\text {hom }}=\left[\frac{\left[M S_{\text {within }}\right]}{n_{0}}\left(\frac{2}{\left[d f_{\text {within }}\right]}\right)^{0.5}\right]^{0.5}
$$

where

$n_{0}$ - the number of repetitions of the measurement for the sample,

$d f_{\text {within }}$ - the number of degrees of freedom within the groups

Based on the results of the above calculations and after comparing the uncertainties associated with the material inhomogeneity for the main components of the materials with the precision of the WD XRF method, all candidate materials were qualified to the next stages of production of certified reference materials [1]. The calculated values of $u_{\text {hom }}$ for both basic and trace components are summarized in Table 3 . The values of $u_{\text {hom }}$ were then included in the budget of uncertainty associated with a certified value.

Table 3. Uncertainty related to material homogeneity $\left(\boldsymbol{u}_{\mathrm{hom}}\right)$

\begin{tabular}{|c|c|c|c|c|c|c|c|c|c|c|c|c|}
\hline & \multicolumn{12}{|c|}{$u_{\text {hom }}, \%$} \\
\hline & $\mathbf{F e}$ & Mn & $\mathrm{TiO}_{2}$ & $\mathrm{CaO}$ & $\mathrm{K}_{2} \mathrm{O}$ & $\mathbf{S}$ & $\mathbf{P}$ & $\mathrm{SiO}_{2}$ & $\mathbf{A l}_{2} \mathbf{O}_{3}$ & MgO* & $\mathrm{Na}_{2} \mathrm{O}^{*}$ & $\mathrm{FeO}^{* *}$ \\
\hline 3.50 & 0.04902 & 0.00026 & 0.00110 & 0.00055 & 0.00014 & 0.00043 & 0.00004 & 0.01678 & 0.00068 & 0.00159 & 0.00148 & 0.02256 \\
\hline 3.51 & 0.02934 & 0.00008 & 0.00034 & 0.00065 & 0.00018 & 0.00026 & 0.00009 & 0.00939 & 0.00098 & 0.00368 & 0.00098 & 0.02236 \\
\hline 3.52 & 0.04451 & 0.00026 & 0.00048 & 0.00033 & 0.00027 & 0.00033 & 0.00006 & 0.00588 & 0.00090 & 0.00283 & 0.00096 & 0.01291 \\
\hline 3.53 & 0.04145 & 0.00037 & 0.00064 & 0.00028 & 0.00008 & 0.00007 & 0.00008 & 0.00980 & 0.00119 & 0.00049 & 0.00035 & 0.01199 \\
\hline 3.54 & 0.04989 & 0.00044 & 0.00047 & 0.00257 & 0.00058 & 0.00003 & 0.00009 & 0.00557 & 0.00316 & 0.00345 & 0.00056 & 0.02582 \\
\hline 3.55 & 0.03855 & 0.00050 & 0.00035 & 0.00025 & 0.00013 & 0.00008 & 0.00022 & 0.02669 & 0.00649 & 0.00007 & 0.00003 & 0.01826 \\
\hline 3.56 & 0.01413 & 0.00105 & 0.00066 & 0.00012 & 0.00007 & 0.00006 & 0.00021 & 0.00105 & 0.00625 & 0.00021 & 0.00020 & 0.01381 \\
\hline 3.57 & 0.05864 & 0.00106 & 0.00028 & 0.00035 & 0.00005 & 0.00005 & 0.00008 & 0.00903 & 0.00258 & 0.00020 & 0.00013 & 0.00116 \\
\hline 3.58 & 0.02820 & 0.00006 & 0.00013 & 0.00373 & 0.00008 & 0.00009 & 0.00004 & 0.00396 & 0.00101 & 0.00183 & 0.00056 & 0.00613 \\
\hline 3.59 & 0.04337 & 0.00019 & 0.00036 & 0.00290 & 0.00029 & 0.00014 & 0.00016 & 0.00964 & 0.00073 & 0.00377 & 0.00091 & 0.02887 \\
\hline
\end{tabular}

Tabela 3. Niepewność związana z jednorodnością materiału ( $\left.\boldsymbol{u}_{\text {jednorodności }}\right)$

\begin{tabular}{|c|c|c|c|c|c|c|c|c|c|c|c|c|}
\hline & \multicolumn{12}{|c|}{$\boldsymbol{u}_{\text {hom }}, \%$} \\
\hline & $\mathbf{C}^{* * *}$ & $\mathbf{P b}$ & As & Zn & $\mathbf{C u}$ & $\mathrm{Ni}$ & Co & $\mathrm{Cr}$ & $\mathbf{V}$ & Cl & $\mathbf{B a}$ & GOI $^{* * * *}$ \\
\hline 3.50 & 0.00021 & 0.00010 & 0.00014 & 0.00009 & 0.00013 & 0.00015 & 0.00015 & 0.00010 & 0.00009 & 0.00036 & 0.00018 & 0.01857 \\
\hline 3.51 & 0.00046 & 0.00010 & 0.00009 & 0.00008 & 0.00014 & 0.00015 & 0.00009 & 0.00005 & 0.00008 & 0.00007 & 0.00014 & 0.03244 \\
\hline 3.52 & 0.00031 & 0.00010 & 0.00013 & 0.00008 & 0.00017 & 0.00013 & 0.00009 & 0.00006 & 0.00010 & 0.00022 & 0.00014 & 0.03257 \\
\hline 3.53 & 0.00020 & 0.00007 & 0.00013 & 0.00008 & 0.00006 & 0.00013 & 0.00016 & 0.00014 & 0.00022 & 0.00033 & 0.00012 & 0.00217 \\
\hline 3.54 & 0.00049 & 0.00009 & 0.00014 & 0.00007 & 0.00007 & 0.00008 & 0.00016 & 0.00023 & 0.00017 & 0.00030 & 0.00016 & 0.01731 \\
\hline 3.55 & 0.00021 & 0.00011 & 0.00014 & 0.00004 & 0.00016 & 0.00013 & 0.00016 & 0.00010 & 0.00013 & 0.00023 & 0.00022 & 0.02153 \\
\hline 3.56 & 0.0001 & 0.00011 & 0.00014 & 0.00013 & 0.00012 & 0.00009 & 0.00012 & 0.00014 & 0.00012 & 0.00028 & 0.00016 & 0.01633 \\
\hline 3.57 & 0.00022 & 0.00014 & 0.00012 & 0.00010 & 0.00009 & 0.00008 & 0.00010 & 0.00012 & 0.00012 & 0.00018 & 0.00019 & 0.02448 \\
\hline 3.58 & 0.00017 & 0.00013 & 0.00007 & 0.00015 & 0.00011 & 0.00015 & 0.00009 & 0.00017 & 0.00010 & 0.00024 & 0.00019 & 0.00133 \\
\hline 3.59 & 0.00044 & 0.00009 & 0.00011 & 0.00009 & 0.00007 & 0.00008 & 0.00011 & 0.00008 & 0.00013 & 0.00037 & 0.00021 & 0.00374 \\
\hline
\end{tabular}

* - ICP OES method, ** - titrimetric method, *** - HFIR method, **** - gravimetric method 


\subsection{ORGANISATION OF A CERTIFICATION ROUND-ROBIN PROGRAM}

Certification analyses were planned with the participation of laboratories with experience in the analysis of chemical composition of iron ores, confirmed by appropriate certificates or positive results of cooperation with the Institute for Ferrous Metallurgy in previous years. This group included fourteen Polish and European laboratories, including the laboratories that would be the possible users of the manufactured certified reference materials. The use of wet methods such as: gravimetric, titrimetric, spectrophotometric, flame AAS, and ICP OES for the certification analysis was ensured.

For trace elements, it was recommended to use the ICP MS and GF AAS methods. In addition to those methods, the use of wavelength dispersion X-ray fluorescence spectrometry (WD XRF) technique, routinely used in laboratories to determine the chemical composition of iron ores was also allowed. The analytical methods used by the laboratories during the certification tests were given unambiguous numbers under which they were identified in the certificates. The certification analysis included, besides the determination of 12 basic components ( $\mathrm{Fe}, \mathrm{SiO}_{2}, \mathrm{CaO}, \mathrm{Al}_{2} \mathrm{O}_{3}, \mathrm{MgO}, \mathrm{Mn}, \mathrm{TiO}_{2}$, $\mathrm{K}_{2} \mathrm{O}, \mathrm{Na}_{2} \mathrm{O}, \mathrm{P}, \mathrm{S}, \mathrm{Cl}$ ), also certification of $\mathrm{FeO}, \mathrm{TiO}_{2}, \mathrm{~V}, \mathrm{Ni}, \mathrm{Cr}$, $\mathrm{Co}, \mathrm{Cu}, \mathrm{Zn}, \mathrm{As}, \mathrm{Pb}, \mathrm{Ba}$ and determination of the loss or gain on ignition (LOI or GOI). Each participant was required to provide uncertainty of the results as well as reference materials used for the verification of their results.

\subsection{STATISTICAL EVALUATION OF THE CERTIFICATION ANALYSIS RESULTS}

The verification of the certification analysis results was carried out first of all through statistical evaluation. In order to detect outliers, the Hampel test was used [5], in which the median is first calculated from the average results sent by the laboratories, and then it is checked whether the calculated absolute value of the difference between this median and the result from a given laboratory does not exceed a certain critical value.

To determine the average values, the Huber test, also called Algorithm-A, recommended by the ISO 35 guide [3], was used. The Huber test, which belongs to the group of iterative robust procedures [6], allows to assess the relatively objective average value of the result and standard deviation. Robust procedures:

- do not reject the information contained in the outlier data, but only reduce its significance (assume a model with the outlier data),

- do not idealise the measurement conditions and the actual distribution model only as Gaussian,

- are a more appropriate way to calculate the uncertainty when the number of samples is small,

- allow to keep the assumption about hypothetical homogeneity of the population for statistical estimation and simultaneously take into account information included in outliers.

Table 4 shows the average values and standard deviations (absolute $-\mathrm{SD}$ and relative - RSD) determined by means of the Huber test as well as other values included in the certificates:

- characterisation uncertainty $\left(u_{\text {char }}\right)$,

- uncertainty associated with homogeneity $\left(u_{\text {hom }}\right)$,

- extended uncertainty $\left(u_{\mathrm{CRM}}\right)$, being the geometric mean of the uncertainty of characterisation and homogeneity uncertainty multiplied by the expansion coefficient $k=2$ :

$$
u_{\text {cRM }}=2 \sqrt{u_{\text {char }}^{2}+u_{\text {hom }}^{2}}
$$

Certified values correspond to average values rounded to one or two significant digits of expanded uncertainty. According to the guidelines presented in publication [7] along with cross-references, the average of results determined according to Algorithm-A should be accepted as:

- a certified value (a) - if the average value has been calculated from at least 4 results obtained using at least two analytical techniques (or not less than 5 results obtained by means of one technique) and the relative standard deviation expressed as a percentage of the average value is not more than $15 \%$ ( $25 \%$ for content below $0.5 \%$ ),

- an informative value (i) - in other cases.

It was decided that the certificates would contain both certified values and informative values, and in those cases where the average was not indicated - individual results of determinations, as detailed in Table 5 .

\subsection{CERTIFICATES AND CATALOGUE CARDS}

The certificates which meet the requirements of ISO GUIDE 31 [8] were developed for the produced certified reference materials. According to these requirements, each certificate contains at least: the title of the document, unique identification (number) of the CRM, name of the CRM, name and address of the Institute (manufacturer), intended range of applications, validity period, storage, handling and use information, page numbers and the total number of pages, document version, specified property, property value and uncertainty associated with it, data confirming traceability of certified values, as well as the name and position of the approving person.

\subsection{SUMMARY}

Ten certified reference materials of chemical composition of iron ores representing the Ukrainian, Russian, Liberian, Brazilian, Norwegian and Canadian deposits were produced. The series, marked with symbols 3.50-3.59, includes: three magnetite concentrates: L-Gok 70\% (3.50), Ju-Gok (3.51), Ingulecki Gok (3.52); two hematite concentrates: Mount Wright (3.53), Mo I Rana (3.54); three raw ores: Mount Tokadeh DSO (3.55), Carajas (3.56), Standard Sinter Feed Tubarao (3.57) and two pellets: L-Gok alkaline (3.58) and Sev-Gok (3.59). The production was carried out in accordance with the requirements of the PN-EN ISO 17034 standard. Table 5 presents the chemical composition of all new certified reference materials that will be available for sale from the second quarter of 2019. In 2020, this series will be enlarged by four successive materials representing Liberian ore from the Mount Gangra field, Mikhailovsky pellets, SevGok2 pellets and the Dniepropietrow concentrate. 


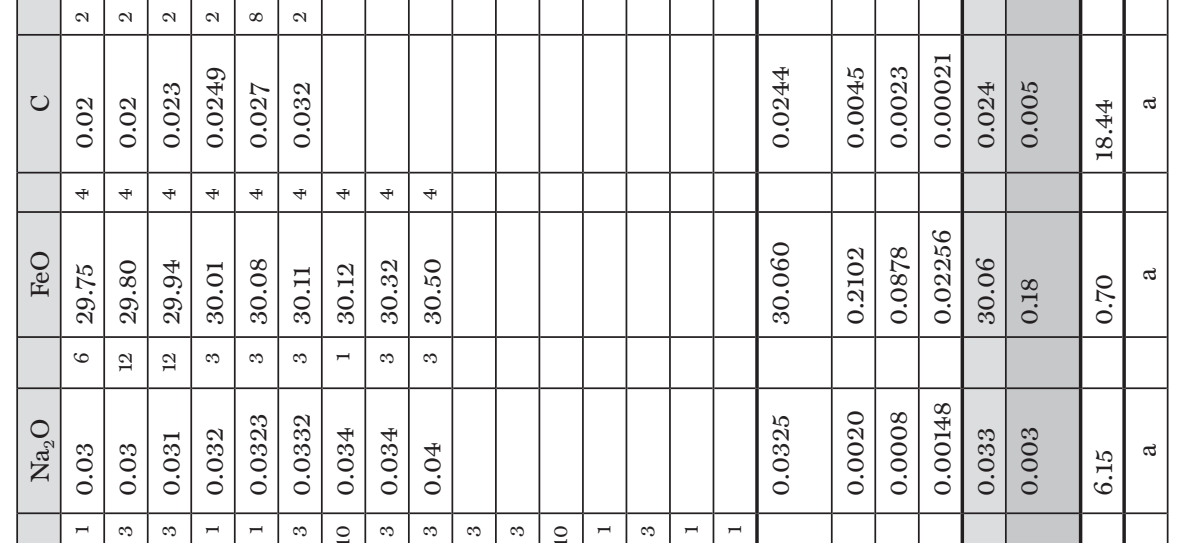

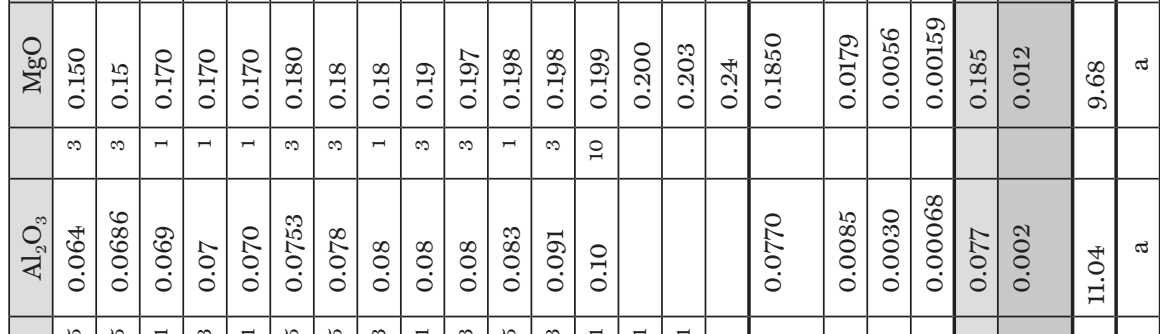

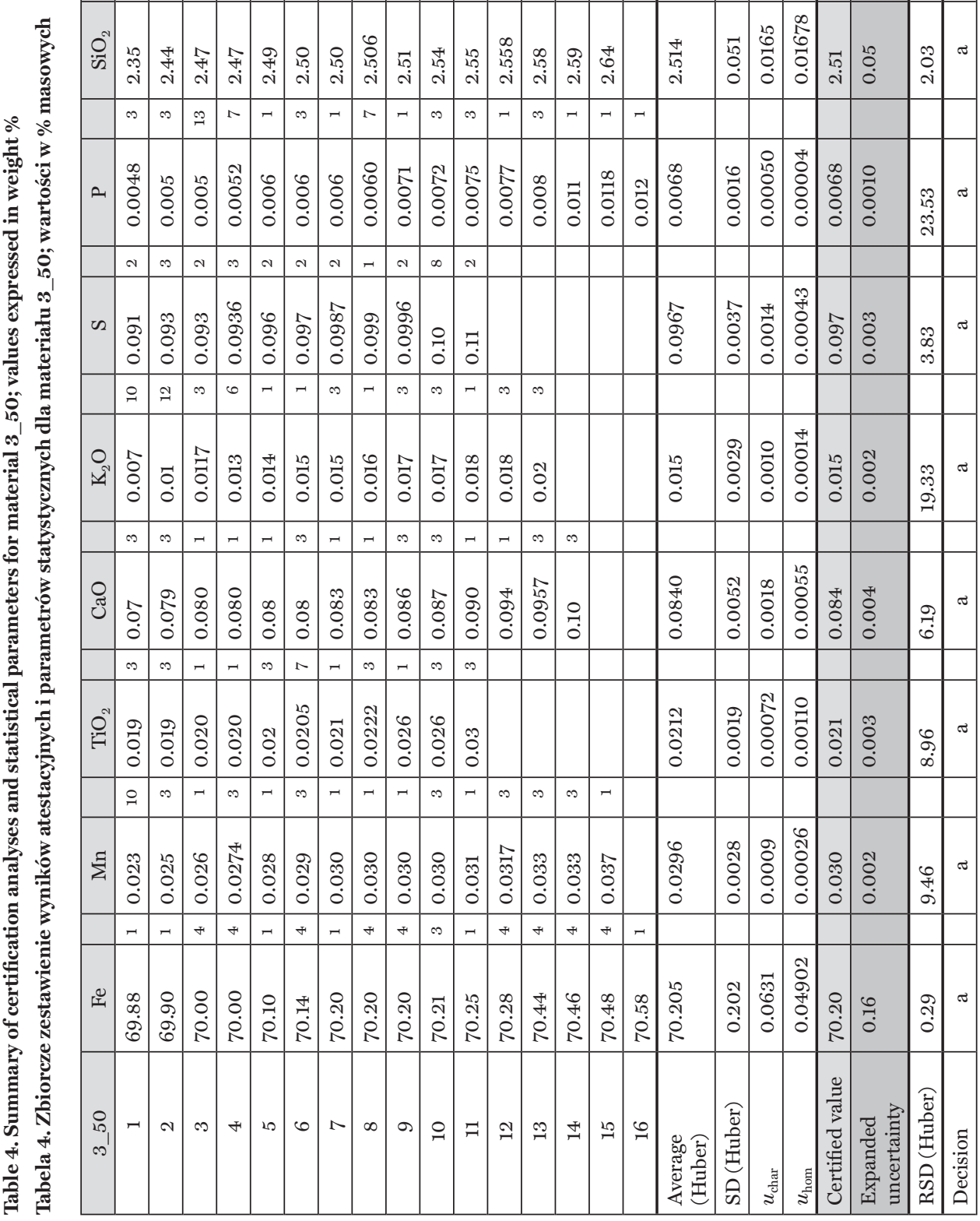




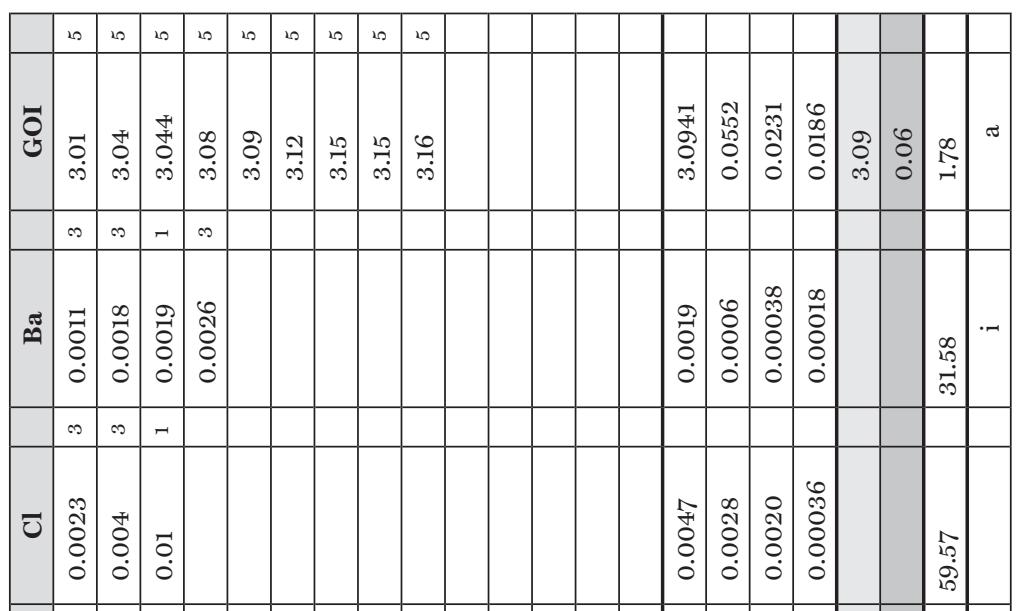

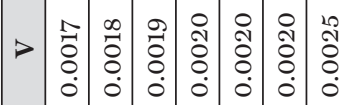

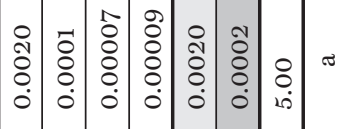

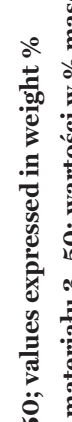

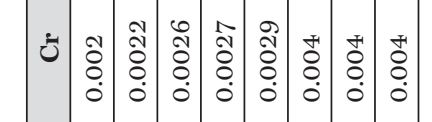

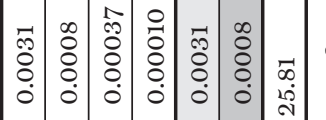

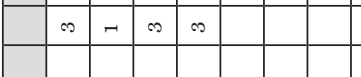

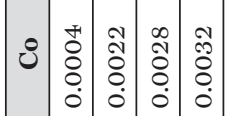

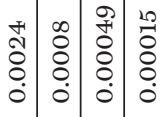

$\infty \quad \rightarrow \infty$

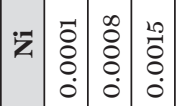

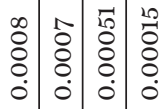

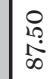

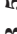

$\infty \begin{array}{lllll}0 & \infty & \infty & 0\end{array}$

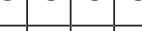

z

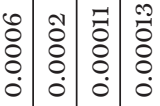

\begin{tabular}{rlllllllllllll}
\hline & 0 & - & - & - & - & $\infty$ & $\infty$ & $\infty$
\end{tabular}

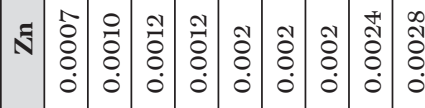

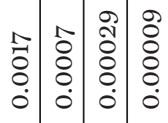

\begin{tabular}{c}
$\infty$ \\
$\stackrel{\infty}{\rightarrow}$ \\
$\overrightarrow{7}$ \\
\hline
\end{tabular}

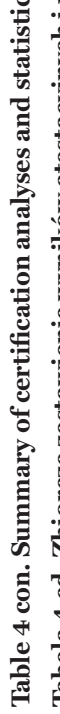

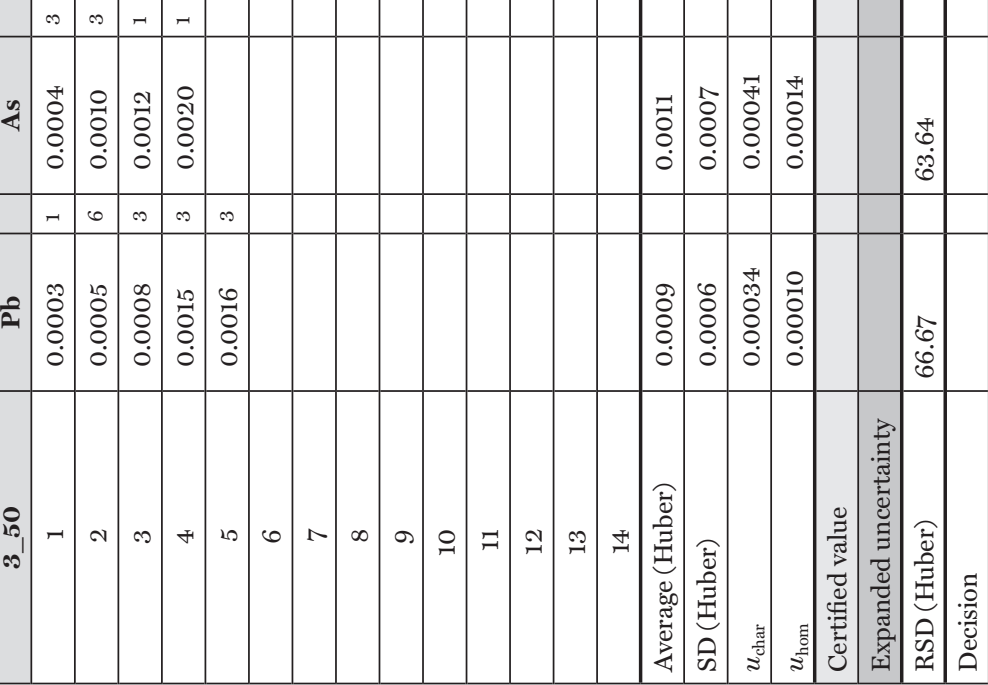


Journal of Metallic Materials 2019, 71 (1), p. 20-26

Table 5. The chemical composition of certified reference materials of iron ores IMŻ3.51 - IMŻ3.59; values expressed in mass \%

Tabela 5. Skład chemiczny certyfikowanych materiałów odniesienia rud żelaza IMŻ3.51 - IMŻ3.59; wartości w \% masowych

\begin{tabular}{|c|c|c|c|c|c|c|c|c|c|c|c|c|}
\hline No. & $\mathrm{Fe}$ & Mn & $\mathrm{TiO}_{2}$ & $\mathrm{CaO}$ & $\mathrm{K}_{2} \mathrm{O}$ & $\mathbf{S}$ & $\mathbf{P}$ & $\mathrm{SiO}_{2}$ & $\mathbf{A l}_{2} \mathbf{O}_{3}$ & MgO & $\mathrm{Na}_{2} \mathrm{O}$ & $\mathrm{FeO}$ \\
\hline 3.50 & 70.20 & 0.030 & 0.021 & 0.084 & 0.015 & 0.097 & 0.0068 & 2.51 & 0.072 & 0.185 & 0.033 & 30.06 \\
\hline 3.51 & 67.55 & 0.012 & 0.010 & 0.095 & 0.018 & 0.023 & 0.0076 & 5.7 & 0.133 & 0.251 & 0.037 & 28.50 \\
\hline 3.52 & 67.84 & 0.032 & 0.015 & 0.297 & 0.020 & 0.061 & 0.018 & 4.56 & 0.206 & 0.553 & 0.030 & 29.04 \\
\hline 3.53 & 66.42 & 0.051 & 0.282 & 0.098 & 0.011 & 0.0050 & 0.018 & 4.07 & 0.399 & 0.055 & 0.012 & 1.41 \\
\hline 3.54 & 62.73 & 0.390 & 0.684 & 1.31 & 0.145 & 0.0149 & 0.028 & 4.78 & 1.48 & 0.494 & 0.096 & 1.41 \\
\hline 3.55 & 59.11 & 0.083 & 0.057 & 0.071 & 0.0072 & 0.013 & 0.090 & 10.06 & 1.92 & $(0.030)$ & 0.011 & 3.86 \\
\hline 3.56 & 64.41 & 0.77 & 0.101 & 0.035 & 0.021 & 0.0084 & 0.040 & 2.85 & 1.63 & 0.057 & 0.011 & $(0.47)$ \\
\hline 3.57 & 62.79 & 0.173 & 0.081 & 0.060 & 0.012 & 0.0064 & 0.058 & 7.08 & 1.07 & 0.047 & 0.010 & 0.95 \\
\hline 3.58 & 66.08 & 0.027 & 0.022 & 2.61 & 0.029 & 0.010 & 0.0066 & 2.60 & 0.214 & 0.229 & 0.032 & 0.84 \\
\hline 3.59 & 61.74 & 0.028 & 0.021 & 2.93 & 0.061 & 0.017 & 0.0078 & 7.75 & 0.248 & 0.856 & 0.079 & 3.17 \\
\hline No. & $\mathbf{P b}$ & As & $\mathrm{Zn}$ & $\mathrm{Cu}$ & $\mathrm{Ni}$ & Co & $\mathrm{Cr}$ & $\mathbf{V}$ & $\mathrm{Cl}$ & $\mathbf{B a}$ & C & GOI/LOI \\
\hline 3.50 & & & $(0.0017)$ & $(0.0006)$ & & $(0.0028)$ & 0.0031 & 0.0020 & & $(0.0019)$ & 0.024 & +3.09 \\
\hline 3.51 & (0.0009) & $(0.0009)$ & $(0.0016)$ & 0.0012 & & $(0.0027)$ & 0.0014 & 0.0009 & 0.043 & (0.0019) & 0.103 & +2.63 \\
\hline 3.52 & $(0.0012)$ & & $(0.0013)$ & (0.0009) & & & 0.0011 & 0.0009 & 0.0133 & (0.0019) & 0.124 & +2.70 \\
\hline 3.53 & (0.0011) & $(0.0007)$ & $(0.0010)$ & 0.0008 & $(0.0017)$ & $(0.0018)$ & 0.0045 & 0.0052 & $(0.0055)$ & & 0.011 & $(-0.086)$ \\
\hline 3.54 & (0.0009) & & 0.0017 & 0.0016 & (0.0018) & $(0.0023)$ & 0.0064 & 0.013 & $(0.0046)$ & $(0.0042)$ & 0.251 & -0.97 \\
\hline 3.55 & 0.0013 & & 0.0020 & $(0.0012)$ & & & 0.0062 & 0.0013 & & & 0.079 & -3.20 \\
\hline 3.56 & 0.0015 & & 0.0066 & 0.0109 & & $(0.0023)$ & 0.0028 & 0.0051 & 0.0093 & 0.028 & 0.043 & -2.37 \\
\hline 3.57 & $(0.0014)$ & $(0.0006)$ & 0.0019 & 0.0014 & (0.0019) & & 0.0039 & 0.0047 & & $(0.0064)$ & 0.054 & -2.15 \\
\hline 3.58 & $(0.0011)$ & $(0.0008)$ & $(0.0013)$ & 0.0008 & $(0.0016)$ & $(0.0016)$ & 0.0034 & 0.0015 & & & $(0.030)$ & -0.056 \\
\hline 3.59 & $(0.0010)$ & & 0.0018 & $(0.0006)$ & & $(0.0014)$ & 0.0023 & 0.0009 & 0.0177 & $(0.0016)$ & 0.036 & +0.13 \\
\hline
\end{tabular}

\section{REFERENCES}

[1] G. Stankiewicz, W. Spiewok, M. Kubiczek. Wytworzenie serii noroych wzorców rud żelaza. Sprawozdanie IMŻ z I etapu pracy badawczej NR 121/BC, 2017. [unpublished].

[2] G. Stankiewicz, W. Spiewok, M. Kubiczek. Wytworzenie serii nowych wzorców rud żelaza. Sprawozdanie IMŻ z II etapu pracy badawczej NR 121/BC, 2018. [unpublished].

[3] ISO Guide 35:2017. Reference materials - Guidance for characterization and assessment of homogeneity and stability.

[4] T.P.J. Linsinger, J. Pauwels, A.M.H. van der Veen, H. Schimmel, A. Lamberty. Homogeneity and stability of reference materials. Accred Qual. Assur., 2001, (6), p. 20-25.

[5] P. Konieczka, J. Namieśnik. Ocena i kontrola jakości wyników pomiarów analitycznych. Warszawa, WNT 2013.
[6] Z.L. Warsza, E.T. Volodarsky. Zastosowanie metod odpornościowych w analizie doktadności pomiarów międzylaboratoryjnych (1). Zasady statystyki odpornościowej, metoda Hubera czyli Algorytm-A. Pomiary Automatyka Robotyka, 2017, (2), p. 47-55.

[7] H. Polkowska-Motrenko, R. Dybczyński. Activities of the INCT, Warsaw, in the domain of quality assurances for inorganic analysis. Journal of Radioanalytical and Nuclear Chemistry, 2006, 269 (2), p. 339-345.

[8] ISO Guide 31:2015. Reference materials - Contents of certificates, labels and accompanying documentation. 